\title{
Cellular and Soluble CD4 Measurements in Cynomolgus Monkeys
}

\author{
Gareth Owain EVANS and Rajni FAGG
}

Drug Safety Evaluation, Wellcome Research Laboratories, Beckenham, Kent BR3 3BS, UK.

(Received 26 October 1993/Accepted 11 May 1994)

\begin{abstract}
Anti-human CD4 monoclonal antibodies have been successfully used to label Tlymphocytes in Cynomolgus monkeys by two different methods. A magnetisable bead separation was used prior to immunogold labelling of lymphocytes in one of the methods. In addition, an assay for soluble CD4 has been applied to the sera of these monkeys. KEY WORDS : CD4, Cynomolgus monkey, immunogold labelling, soluble CD4, Tlymphocytes
\end{abstract}

There is evidence that lymphocytes from non-human primate species cross react with monoclonal antibodies (MABs) which show specificity towards human lymphocytes, and this includes MABs for the cluster differentiation 4 (CD4) antigen [1-11]. This CD4 antigen is expressed on the cell membranes of thymus derived lymphocytes, helper/inducer $\mathrm{T}$ cells and to a lesser extent on monocytes and macrophages in man [12], and it is used as a marker for disease progression and treatment in acquired immune disease syndrome (AIDS) .

The objectives of this study were to measure $\mathrm{CD} 4$ reactive lymphocytes and the levels of soluble CD4 in peripheral blood from cynomolgus monkeys (Macaca fascicularis) using different techniques. The lymphocytes were enumerated using two different cell counting methods: an immunogold labelling technique with microscocpic counting method of labelled cells and a flow cytometric method with fluoroscein isothiocyanate (FITC-conjugated $\mathrm{MAb}$. A 'sandwich' enzyme linked immunoassay for soluble $\mathrm{CD} 4$ ( $\mathrm{sCD} 4$ ) designed for use with human sera was applied to sera from cynomolgus monkeys.

\section{Materials and Methods}

Animals and blood samples: Blood samples were collected from the femoral veins of inbred cynomolgus monkeys, following sedation with Ketamine : the male and female animals were aged 2 to 6 years. The blood was added to tubes containing dipotassium ethylenediamine tetraacetic acid ( 1.5 to $2 \mathrm{mg} / \mathrm{m} \ell$ of blood) or into plain tubes for serum separation.

For sCD4 assays, eighteen sera were obtained following centrifugation at $12,000 \mathrm{~g}$ for $2 \mathrm{~min}$. These samples were stored at $-20^{\circ} \mathrm{C}$ prior to analysis. A separate study had shown that the samples appeared to give similar results when stored at $-20^{\circ} \mathrm{C}$ for up to 28 days. Total white blood cell and lymphocyte counts: The total leucocyte count was determined using a Sysmex E5000 blood cell counter (Toa Medical Electronics Co. Ltd., Kobe, Japan). Total lymphocyte counts were carried out by microscopic examination, after staining blood films with a modifed Polychrome Methylene blue reagent (Ames Laboratories, Stoke Poges, U. K.).

Immunogold labelling method: Immunogold labelling methods previously described, and used in this laboratory for labelling rat and canine T-lymphocytes [13-15] were modified by the introduction of Dynabeads ${ }^{\mathrm{TM}}$ for the separation of lymphocytes from the whole blood sample. The Dynabeads (product M450CD4 ; Dynal AS, Oslo, Norway) are magnetisable polystyrene beads coated with a mouse anti-human CD4 MAb (anti-CD4 beads). These beads were used according to the manufacturer' $s$ instructions, and enabled the separation of cells which bind to the anti-CD4 beads; the detachment of the cells from the beads occurs during an overnight suspension period of $20 \mathrm{hr}$.

The cells were then labelled with a mouse 
Table 1. T-lymphocyte, lymphocyte and leucocyte counts in cynomolgus peripheral blood samples

\begin{tabular}{ccc}
\hline $\begin{array}{c}\text { T-lymphocytes } \% \\
\text { Mean (SD) } \\
\text { Range }\end{array}$ & $\begin{array}{c}\text { Lymphocytes } \times 10^{9} / 1 \\
\text { Mean (SD) } \\
\text { Range }\end{array}$ & $\begin{array}{c}\text { Leucocytes } \times 10^{9} / \mathrm{L} \\
\text { Mean (SD) } \\
\text { Range }\end{array}$ \\
\hline $\begin{array}{c}\text { Group } 1(\mathrm{n}=12) \\
\text { Immunogold method } \\
24(3)\end{array}$ & $2.18(1.13)$ & $4.06(0.92)$ \\
14 to 38 & 1.9 to 3.5 & 2.8 to 5.5 \\
Group $2(\mathrm{n}=10)$ & & $2.60(0.58)$ \\
Immunogold method & & 2.0 to 3.2 \\
$18(4)$ & $1.78(0.43)$ & \\
13 to 23 & 1.4 to 2.2 & \\
FITC method & & \\
24 ( 6$)$ & & \\
17 to 33 & & \\
\end{tabular}

anti-human CD4 MAb (product MCA 481; Serotec Oxford, U. K) and then with a goat anti-mouse IgG conjugated Immu-Mark ${ }^{\mathrm{TM}}$ gold probe (probe size $20 \mathrm{~nm}$, product $678552:$ ICN Biomedicals, High Wycombe, U. K.). Positively labelled cells with blue black gold particles were then counted using a light microscope, and the results were expressed as percentages of the total number of lymphocytes. FITC-flow cytometry method : FITC conjugated antibody mouse anti-human CD4 $(20 \mu l$, product MCA 635F ; Serotec, Oxford, U. K.) was incubated with whole blood $(100 \mu \ell)$ for 15 $\mathrm{min}$ at room temperature. Erythrocytes were removed by the addition of a lysing agent (FACS $^{\mathrm{TM}}$ lysing solution, product 92-002 ; Becton-Dickinson, California, U. S. A.) : red cell stroma was then discarded by centrifugation and washing with phosphate buffered saline. The FITC-labelled cells were then fixed using $1 \%$ paraformaldehyde prior to analysis by flow cytometry. A FACS ${ }^{\mathrm{TM}}$ IV cytometer (Becton-Dickinson, California, U. S. A.) was appropriately gated for lymphocyte counting. Negative controls were prepared using an antibody of the same isotype as the test antibody (mouse anti-human negative control, product MCA 690F; Serotec). The FITC labelled mouse anti human $\mathrm{CD} 4$ was from the same clone as used for immunogold labelling.

Soluble CD4 : The measurement was performed with Cellfree ${ }^{\mathrm{TM}} \mathrm{CD} 4$ test kit ( $\mathrm{T}$ Cell Sciences Inc., Cambridge, MA, U. S. A) according to the manufacturer's instructions. An anti-CD4 $\mathrm{MAb}$ is adsorbed onto microtitre plate wells and samples and standards are added to the appropriate wells. Following washing procedure to remove non-reactive materials, horse raddish peroxidase conjugated anti $\mathrm{CD} 4-\mathrm{MAb}$ (HRPMAb) was added to form the 'sandwich'. Unbound HRPMAb was removed by washing and o-phenylene diamine was added to measure degree of bound peroxidase activity colorimetrically at $492 \mathrm{~nm}$. Six standards, containing a recombinant human $\mathrm{CD} 4$, were used to construct a calibration curve and determine the amount of $\mathrm{sCD} 4$ in the samples [16].

Using a pooled cynomolgus serum, the within-run coefficient of variation was $1.0 \%$ and the intra-run coefficient of variation was $0.83 \%$ at a level of $20 \times 10^{3} \mathrm{U} / 1 \quad(\mathrm{n}=24)$. Recovery experiments were performed by assaying three cynomolgus sera before and after the addition of the $40 \times 10^{3} \mathrm{U} / 1$ human recombinant standard (supplied with the kit) to these samples. The original mean values and percentage recoveries were 15,17 and $21 \times 10^{3} \mathrm{U} / 1$ and 90 , 80 and $68 \%$ respectively, after correction for dilution of the monkey plasma with the recombinant standard.

\section{Results}

Positively labelled CD4 lymphocytes were observed in two groups of peripheral blood sample obtained from cynomolgus monkeys using the immunogold and immunoflurorescence methods : the data obtained by both methods are shown in Table 1. Samples from Group 2 were analysed by both methods; the values 
obtained by the flow cytometric method were slightly higher than those with the immunogold method. However these results were similar to those obtained in the first group with immunogold labelling.

The sCD4 values obtained for cynomolgus sera ranged from 6 to $27 \times 10^{3} \mathrm{U} / 1$, with mean and standard deviation values being 21 and $7 \times$ $10^{3} \mathrm{U} / 1$, respectively .

\section{Discussion}

Although mouse anti-human CD4 monoclonals do not always recognise CD4 epitopes in non-human primates $[10,17]$, this study has demonstrated anti-CD4 reactivity in cynomolgus monkeys using two cell labelling techniques. One published report stated that there were no positively reactive cells with antihuman CD4/Leu3a[5], and another report suggested $33 \%$ of the lymphocytes were reactive with anti CD4/T4 MABs [2] in this species.

The introduction of a magnetic separation device for lymphocyte preparation appears to be a useful but time-consuming procedure. Of the two techniques, the FITC-flow cytometric method is preferred, but many laboratories still do not have access to such equipment. One advantage of the flow cytometric method may be the use of paraformaldehyde to fix cells particularly from immunocompromised animals with obvious or latent viral infections, although several other problems may occur with $\mathrm{T}$-cell subset enumeration using flow cytometry $[18,19]$. There are insufficient data in this study to comment on age-related changes reported for other non-human primates $[7,8]$, and we have not studied intraanimal physiological variations.

From these preliminary studies, it appears that $\mathrm{sCD} 4$ assays may be worthy of further investigation in disease states where levels of sCD4 may alter in cynomolgus monkeys. The range of values observed for cynomolgus monkeys was slightly narrower than that obtained for human sera ( 8 to $\left.65 \times 10^{3} \mathrm{U} / \mathrm{l}\right)$ using the same assay.

\section{References}

[1] Haynes, B. F., Dowell, B. L. Hensley, L. L., Gore, I., and Metzgar R. S. (1982). Human T cell antigen expression by primate T cells. Science, 215, 298-299.

[2] Letvin, N. L., King, N. W., Reinberg, E. L.,
Hunt, R. D., Lane, H., and Schlossman, S. F. (1983). T lymphocyte surface antigens in primates. Eur. J. Immunol., 13, 345-347.

[ 3 ] Martin, L. N., Gormus, B. J., and Bozelka, B. E. (1983). Functional analysis of monkey lymphocyte subsets defined by OKT 4 and OKT 8 monoclonal antibodies. Cell. Immunol., 11, 338-347.

[4] Schooley, R. T., Byington, R., and Falk, L. A. (1983). Phenotypic analysis of New world primate mononuclear cell surface antigens. J. Med. Primatol., 12, 30-40.

[5] Murayama, Y., Fukao, K., Noguchi, A., and Ta. kenaka, O. (1986). Epitope expression on primate lymphocyte surface antigens. J. Med. Primatol. , 15. 215-226.

[6] O'Neill, P. A. and Levy, B. M. (1986). Lymphocyte subsets in the young and aging marmoset (Callithrix jacchus). J. Med. Primatol., 15, 409-417.

[7] Eichberg, J. W., Montiel, M. M., Morale, B. A., King, D. E., Chanh, T. C., Kennedy, R. C., and Dreesman, G. R. (1988). Lymphocyte subsets in chimpanzees. Lab. Animal. Sci., 38, 197-198.

[8] Lee, Y-C. C., Lawless, D., Crook, J. E., and Clapp, N. K. (1989). Case report: analysis of T lymphocyte subsets in Tamarins with colitis and colon cancer. Am. J. Med. Sci., 297, 118-122.

[9] Jonker, M. and Slingerland, W. (1989). Reaction of monoclonal antibodies specific for human CD markers with rhesus monkey leucocytes. In Leucocyte Typing 1V, PP. 1058-1063, Knapp, B., W. Dorken, W. R. Gilks, P. Rieber, R. E. Schmidt, H. Stein, and von dem Borne, A. E. G. K. (eds.), Oxford University Press, Oxford.

[10] Jonker, M. (1990). The importance of non-human primates for preclinical testing of immunosuppressive monoclonal antibodies. Semin. Immunol., 2, 427436.

[11] Tryphonas, H., Luster, M. I., Schiffman, G., Dawson, L-L., Hodgen, M., Germolec, D., Hayward, S., Bryce, F., Loo, J. C. K., Mandy, F., and Arnold, D. L. (1991). Effect of chronic exposure of PCB (Aroclor 1254) on specific and nonspecific immune parameters in the rhesus (Macaca mulatta) monkey. Fund. Appl. Toxicol., 16, 773-786.

[12] Sattentau, Q. J. and Weiss, R. A. (1988). The CD4 antigen: physiological ligand and $\mathrm{H} 1 \mathrm{~V}$ receptor. Cell, 52, 631-633.

[13] de Waele, M., de Mey, J., Moeremans, M., de Brabander, M., and van Camp, B. (1983). Im. munogold staining methods for the detection of cell surface antigens with monoclonal antibodies. In Techniques in Immunocytochemistry, Academic Press Inc. Ltd., London.

[14] Evans, G. O., Flynn, R. M., and Lupton, J. D. (1988). An immunogold labelling method for the enumeration of canine T-lymphocytes. Vet. Quart., 10, 273-276.

[15] Evans, G. O., Flynn, R. M., and Lupton, J. D. (1988). Immunogold cell labelling method for rat $\mathrm{T}$ lymphocytes. Lab. Animals, 22, 332-334.

[16] Reddy, M. M., Vodian, M., and Grieco, M. H (1990). Elevated levels of CD4 antigen in sera of human immunodeficiency virus-infected populations. J. Clin. Microbiol., 28, 1,744-1,746.

[17] Hall, B. M. (1989). Therapy with monoclonal anti- 
bodies to $\mathrm{CD} 4$ : potential not appreciated? $\mathrm{Am} . \mathrm{J}$. Kidney. Dis. XIV : Suppl., 2, 71-77.

[18] Kidd, P. G. and Vogt, R. F. (1989). Report of the workshop on the evaluation of $\mathrm{T}$-cell subsets during HIV infection and AIDS. Clin. Immunol. Im. munopathol., 52, 3-9.
[19] Paxton, H., Kidd, P., Landay, A., Giorgi, J., Flomenberg, N., Walker, E., Valentine, F., Fahey, J., and Gelman, R. (1989). Results of the flow cytometry ACTG quality control program : analysis and findings. Clin. Immunol. Immunopathol., 52, 6884 .

\section{カニクイザルにおける細胞性および可溶性 CD4の測定 \\ エバンス， G. O.・ファッグ， R.}

ウエルカム研究所薬剤安全性評価部門

抗ヒトCD4モノクロナール抗体を使用して，2つの 異なる方法により，カニクイザルのTリンバ球を標識 することができた。そのうちの一方では, 磁気化でき るビーズを用いた分離法を行った後, リンバ球をイム
ノゴールド（金結合抗体）によって標識した。さらに， 可溶性 CD4の定量をこれらのサルの血清について行っ た。 